\title{
Paracoccus thiocyanatus Sp. nov., a new species of thiocyanate-utilizing facultative chemolithotroph, and transfer of Thiobacillus versutus to the genus Paracoccus as Paracoccus versutus comb. nov. with emendation of the genus
}

\author{
Yoko Katayama, ${ }^{1}$ Akira Hiraishi ${ }^{2}+$ and Hiroshi Kuraishi ${ }^{3}$
}

1 Faculty of Agriculture, Tokyo University of Agriculture and Technology, Fuchu, Tokyo183, Japan

2 Laboratory of Environmental Biotechnology, Konishi Co., Sumida-ku, Tokyo 130, Japan

3 Japan Food Research Laboratories, Shibuya-ku, Tokyo 151, Japan
Author for correspondence: Yoko Katayama. Tel: +8142367 5732. Fax: +81423608830 .

\begin{abstract}
A facultatively chemolithotrophic thiocyanate-degrading bacterium, strain THI 011', which was previously isolated from activated sludge and tentatively named Thiobacillus sp., was studied taxonomically and phylogenetically. This bacterium utilizes thiocyanate as sole energy source and the specific growth rate for chemolithoautotrophic growth with thiocyanate was $0.059 \mathbf{h}^{-1}$. Molecular phylogenetic relationships of strain TH $011^{\top}$ to Thiobacillus versutus and members of the genus Paracoccus were elucidated by comparing 165 rRNA gene sequences. Binary sequence comparisons showed that strain $\mathrm{THI} 011^{\mathrm{T}}$ was most related to Paracoccus aminophilus, at a similarity level of $97.0 \%$, and $T$. versutus was most similar to Paracoccus denitrificans, at a level of $99 \cdot 1 \%$. A neighbour-joining phylogenetic tree showed that strain $\mathrm{THI} 011^{\top}$ formed a cluster together with $T$. versutus and known species of the genus Paracoccus within the $\alpha-3$ subclass of the Proteobacteria. DNA-DNA hybridization assays and phenotypic studies indicated that strain TH $011^{\mathrm{T}}$ differed from $\mathrm{T}$. versutus and known species of the genus Paracoccus. On the basis of these results, we propose to classify strain THI $011^{\top}$ into a new species of the genus Paracoccus with the name Paracoccus thiocyanatus sp. nov. We also propose to transfer $T$. versutus to the genus Paracoccus and present an emended description of the genus.
\end{abstract}

Keywords: thiocyanate degradation, Paracoccus thiocyanatus sp. nov., Paracoccus versutus comb. nov., Thiobacillus versutus, molecular phylogeny

\section{INTRODUCTION}

Thiocyanate, which is formed chemically from cyanide by the addition reaction of sulphur, is one of the major constituents of wastewater from coke-oven factories, and biological degradation of this sulphur compound in wastewater is a subject of major concern. Stafford \& Callely (1969) isolated a Pseudomonas stutzeri-like chemoorganotroph that used thiocyanate as nitrogen and sulphur sources. Pseudomonas sp. (Putilina, 1961) and

†Present address: Central Research Laboratories, Ajinomoto Co., Inc., Kawasaki-ku, Kawasaki 210, Japan.

The DDBJ, EMBL, GSDB and NCBI accession numbers for the 165 rDNA nucleotide sequence data reported in this paper are D32238 to D32244.
Artbrobacter sp. (Betts et al., 1979) were also reported as thiocyanate-degrading bacteria. Some obligately chemolithotrophic species of the genus Tbiobacillus, such as $T$. thioparus (Happold et al., 1958; Katayama \& Kuraishi, 1978) and T. denitrificans (Wood, 1975), are known to use thiocyanate as an energy source for growth. Happold et al. (1954) isolated the obligate chemolithotroph T. thiocyanoxidans, which uses thiocyanate as energy and nitrogen source with production of carbon dioxide, ammonium and sulphate (Youatt, 1954). There are phenotypic similarities between $T$. thioparus and T. thiocyanoxidans, the latter of which has been classified as $T$. thioparus since the publication of the 8th edition of Bergey's Manual of Determinative Bacteriology (Vishniac, 1974). Recently, thiocyanate hydrolase, a novel enzyme which catalyses the 
formation of carbonyl sulphide and ammonia from thiocyanate, was found in T. thioparus (Katayama et al., 1992). However, thiocyanate degradation by the facultatively chemolithotrophic sulphur bacteria has not yet been described.

Members of the genus Thiobacillus are Gram-negative, aerobic, mesophilic, non-sporeforming, rod-shaped bacteria which are specialized in their ability to oxidize reduced sulphur compounds (Kelly \& Harrison, 1989). Early taxonomic studies of Thiobacillus species showed their diversity in nutritional requirements, chemolithotrophic energy source utilized, $\mathrm{pH}$ ranges for growth, and DNA base composition (Hutchinson et al., 1969; Jackson et al., 1968), and the genus Tbiobacillus has been considered to include heterogeneous bacterial groups above the generic level. Previously, we classified Thiobacillus species into three major categories, groups I, II and III, on the basis of phenotypic and chemotaxonomic criteria (Katayama-Fujimura et al., 1982). Group I includes the facultative chemolithotrophs containing ubiquinone-10 (Q-10) as the principal quinone; $T$. acidophilus, $T$. novellus and $T$. versutus are members of this group. Group II encompasses the facultative chemolithotrophs with Q-8, and comprises $T$. delicatus, $T$. intermedius and $T$. perometabolis. The obligate chemolithotrophs with Q-8 are placed in group III, members of which are $T$. denitrificans, $T$. ferrooxidans, $T$. neapolitanus, $T$. thiooxidans and $T$. thioparus (the type species). In addition to the chemolithotrophy and quinone profiles, there are marked differences in sulphur requirements for growth and cellular fatty acid compositions among strains of different groups of thiobacilli (Katayama-Fujimura et al., 1982, 1984a). The grouping of thiobacilli based on these phenotypic differences has been supported by sequence comparisons of small-subunit rRNAs (5S and 16S). Thiobacillus species of groups II and III so far examined belong to the $\beta$ subclass of the Proteobacteria (Stackebrandt et al., 1988), whereas those of group I are in the $\alpha$ subclass (Lane et al., 1992; Huber \& Stetter, 1990; Drobner et al., 1992). Recently, Ludwig et al. (1993) verified the close relationship between $T$. versutus and Paracoccus denitrificans, as well as synonymy of the latter species and Thiosphaera pantotropha, using the $16 \mathrm{~S}$ rRNA sequence information. In addition, phylogenetic relationships between $T$. acidopbilus and Acidiphilium species were mentioned by Lane et al. (1992).

Although the ability to oxidize reduced sulphur compounds under chemolithotrophic growth conditions is an important criterion for the classification and the identification of Thiobacillus species, the available information strongly implies that at least the species of group I should be removed from the genus Thiobacillus and be reclassified into appropriate known or new genera. The main purpose of the present study was to characterize strain THI $011^{\mathrm{T}}$, a Gram-negative thiocyanate-degrading facultatively chemolithotrophic sulphur bacterium which in previous studies was classified into group I and tentatively called Thiobacillus sp. (Katayama-Fujimura et al., 1983a, 1984 b, c). Since phenotypic studies are no longer thought to provide information of value, without molecular phylogenetic data, in generic reassignment of the group I thiobacilli, we attempted to elucidate phylogenetic relationships between the new isolate and related bacteria including $T$. versutus and members of the genus Paracoccus by studying $16 \mathrm{~S}$ rRNA gene sequence data. In this paper, we first describe phylogenetic relationships of strain THI $011^{\mathbf{T}}$ and related bacteria, and then make a comparison of the physiological characteristics of these organisms. We propose to create a new species, Paracoccus thiocyanatus, for strain THI $011^{\mathrm{T}}$. We also propose to transfer T. versutus to the genus Paracoccus as Paracoccus versutus with emendation of the genus.

\section{METHODS}

Strains used. Strain THI $011^{\mathrm{T}}$ ( $\mathrm{T}=$ type strain), which was previously named Tbiobacillus sp., two strains of T. versutus, and the type strains of known members of the genus Paracoccus, Rbodobacter capsulatus and Rbodobacter spbaeroides were studied. Detailed information on these test strains is given in Table 1. All test organisms were maintained on BY agar medium (KatayamaFujimura \& Kuraishi, 1980), except for the phototrophic bacteria, for which MYCA medium (Hiraishi et al., 1991) was used, and all were subcultured monthly.

Phenotypic characterization. Morphological and physiological characteristics were examined as described previously (Katayama-Fujimura \& Kuraishi, 1980; Katayama-Fujimura et al., 1983b). Unless otherwise noted, all the tests were carried out at $30^{\circ} \mathrm{C}$ in SM medium (Katayama-Fujimura et al., 1982) supplemented with an appropriate growth substance such as thiosulphate $\left(5 \mathrm{~g} \mathrm{l}^{-1}\right)$ and glucose $\left(10 \mathrm{~g} \mathrm{l}^{-1}\right)$. For growth of strain THI $011^{\mathrm{T}}$ in the synthetic medium, thiamin $\left(200 \mu \mathrm{g} \mathrm{l}^{-1}\right)$ was added as the growth factor. Growth with potassium thiocyanate ( $3.5 \mathrm{~g} \mathrm{l}^{-1}$ ) was examined in TC medium (KatayamaFujimura \& Kuraishi, 1980). Concentrations of thiosulphate, sulphate and thiocyanate were determined as described previously (Katayama \& Kuraishi, 1978; Katayama-Fujimura et al., 1983b).

Analyses of quinones and fatty acids. Quinones were extracted with chloroform/methanol, purified by thin-layer chromatography, and then analysed by high-performance liquid chromatography (HPLC) (Ohara et al., 1990). Fatty acids were extracted after saponification, methylated with diazomethane, and then analysed by gas-liquid chromatography (KatayamaFujimura et al., 1982). The results are reported as percentage composition of non-hydroxyl fatty acids, and also as the amount of hydroxyl fatty acid relative to the total amount of nonhydroxyl fatty acids. We used the combined values of [octadecenoic acid $\left(\mathrm{C}_{18: 1}\right)+$ cyclopropane acid of $\mathrm{C}_{19}\left(\mathrm{C}_{19 \mathrm{cyc}}\right)$ ], because this combined value shows less variation with growth phase (Katayama-Fujimura \& Kuraishi, 1980).

DNA base composition and DNA-DNA hybridization. Chromosomal DNA was extracted and purified by the method of Marmur (1961). The guanine plus cytosine $(G+C)$ content of DNA was determined by HPLC of nuclease $\mathrm{P} 1$ hydrolysates of the DNA (Katayama-Fujimura et al., 1984b). DNA-DNA reassociation assays were performed by the quantitative dotblot hybridization method with photobiotin labelling and colorimetric detection (Ezaki et al., 1988; Hiraishi et al., 1991). The level of hybridization was determined by measuring the colour intensity of hybridized spots with a Shimadzu model CS9000 two-dimensional computing densitometer.

Amplification and sequencing of 165 rRNA genes. Cells were grown in $5 \mathrm{ml} \mathrm{NB}$ liquid medium, harvested by centrifugation 
Table 1. Bacterial strains studied and nucleotide sequence accession numbers for their 16S rDNAs

\begin{tabular}{|c|c|c|c|c|}
\hline Species & $\begin{array}{c}\text { Strain } \\
\text { designation } \\
\text { or received } \\
\text { as: }\end{array}$ & Other designations/sources & Reference* & $\begin{array}{c}\text { Sequence } \\
\text { accession } \\
\text { no. } \dagger\end{array}$ \\
\hline Thiobacillus sp. & THI $011^{\mathrm{T}}$ & IAM12816 $6^{\mathrm{T}}$, IFO $14569^{\mathrm{T}}, \mathrm{H}$. Murooka $1-8 \mathrm{~A}^{\mathrm{T}}$ & 1 & D32242 \\
\hline Thiobacillus versutus & IAM $12814^{\mathrm{T}}$ & ATCC $25364^{T}$, IFO $14567^{T}$ & 2,3 & D32243 \\
\hline Thiobacillus versutus & IAM 12815 & ATCC 27793, IFO 14568 & 3 & D32244 \\
\hline Paracoccus denitrificans & IAM $12479^{\mathbf{T}}$ & ATCC $17741^{\mathrm{T}}$ & 4,5 & \\
\hline Paracoccus denitrificans & IFO 13301 & ATCC 19367, DSM 65 & 4 & \\
\hline Paracoccus aminophilus & $\mathrm{JCM} 7686^{\mathrm{T}}$ & ATCC $49673^{T}$, T. Urakami DM-15 $5^{\mathrm{T}}$ & 6 & D32239 \\
\hline Paracoccus aminovorans & $\mathrm{JCM} 7685^{\mathrm{T}}$ & ATCC $49632^{\mathrm{T}}$, T. Urakami DM-82 ${ }^{\mathrm{T}}$ & 6 & D32240 \\
\hline Paracoccus alcaliphilus & $\mathrm{JCM} 7364^{\mathrm{T}}$ & Urakami TK $1015^{\mathrm{T}}$ & 7 & D32238 \\
\hline Paracoccus kocurii & $\mathrm{JCM} 7684^{\mathrm{T}}$ & ATCC $49631^{\mathbf{T}}$, Y. Katayama strain $\mathbf{B}^{\mathbf{T}}$ & 8 & D32241 \\
\hline Rhodobacter capsulatus & DSM $1710^{T}$ & ATCC $11166^{\mathrm{T}}$ & 9 & \\
\hline Rhodobacter sphaeroides & DSM $158^{T}$ & ATCC $17023^{\mathrm{T}}$, IFO $12203^{\mathrm{T}}$ & 9 & \\
\hline
\end{tabular}

*1, Katayama-Fujimura et al. (1983a); 2, Harrison (1983); 3, Katayama-Fujimura et al. (1983b); 4, Davis et al. (1969); 5, Ludwig et al. (1993); 6, Urakami et al. (1990); 7, Urakami et al. (1989); 8, Ohara et al. (1990); 9, Hiraishi \& Ueda (1994).

+ Accession numbers are indicated only for the sequences determined in this study.

in the late-exponential phase of growth, washed with sterile $1 \%$ $(\mathrm{w} / \mathrm{v})$ saline, resuspended in $100 \mu \mathrm{l}$ sterile distilled water, and stored at $-20^{\circ} \mathrm{C}$ until used. Crude lysates were prepared from stock cell suspensions by protease digestion, heat treatment, and centrifugation. Fragments of $16 \mathrm{~S}$ rDNA that corresponded to positions 8-1510 were amplified by the polymerase chain reaction (PCR) from the crude extract and sequenced directly by the combined method consisting of linear PCR sequencing and automated fluorescent detection. All numbers referring to positions of $16 \mathrm{~S}$ rRNA were based on the Escherichia coli numbering system (Brosius et al., 1978). Details of the procedure used here have been described previously (Hiraishi, 1992; Hiraishi et al., 1994).

Phylogenetic analysis. Pairs of sequences were aligned, and percentage similarities were calculated with the GENETYX program (Software Development Co., Tokyo, Japan). Multiple alignment of sequences, calculation of nucleotide substitution rates $\left(K_{\text {nuc }}\right)$ (Kimura, 1980) and construction of neighbourjoining phylogenetic trees (Saitou \& Nei, 1987) were performed with the CLUSTAL v program (Higgins et al., 1992). Alignment positions that included gaps and unidentified bases were not taken into consideration for the calculations. The topology of the phylogenetic tree was evaluated by performing a bootstrap analysis (Felsenstein, 1985) with 1000 bootstrapped trials.

\section{RESULTS}

\section{Phylogenetic analysis}

Because strain THI $011^{\mathrm{T}}$ has several phenotypic characteristics similar to $T$. versutus (see below), and T. versutus is closely related to $P$. denitrificans (Ludwig et al., 1993), the phylogenetic relationship of strain THI $011^{\mathrm{T}}$ to $T$. versutus and species of Paracoccus was examined. Nearly full-length fragments of the 16S rDNAs from the seven test strains were amplified by PCR and sequenced by the linear PCR sequencing method. All of the sequences which we determined covered a continuous nucleotide stretch from positions 28 to 1492 , including 1383 to 1387 residues. Signature analysis of 60 nucleotide positions important for distinguishing between the four subdivisions (Woese, 1987) of the Proteobacteria also suggested that these strains belonged to the $\alpha$ subdivision. The substantially shorter sequences of the test organisms compared to the E. coli sequence were due to large deletions of loop helices around positions $80,210,470$ and 1270. Also, the sequences of all test organisms were characterized by insertion of 1 or 2 bases into the loop stem around position 1450. These features of the sequence data indicated that all test organisms belong to the $\alpha-3$ subclass of the Proteobacteria.

The sequences determined in this study were compared with eight sequences published previously for representative members of the $\alpha-3$ subclass, including $P$. denitrificans and some species of phototrophic bacteria (Hiraishi \& Ueda, 1994), with the E. coli sequence as an outgroup. Table 2 shows the levels of binary sequence similarity and evolutionary distance $\left(K_{\text {nuc }}\right)$ values based on the multiple alignment of the 1345 positions. Pairwise sequence comparisons showed that strain $\mathrm{THI} 011^{\mathbf{T}}$ was most closely related to $P$. aminophilus, at a similarity level of $97.0 \%$. The two strains of $T$. versutus had identical sequences, and exhibited the highest affinity to $P$. denitrificans, at a similarity level of $99 \cdot 1 \%$. The known species of the genus Paracoccus were related to each other at similarity levels between $95.5 \%$ and $97.0 \%$, and showed lower levels of similarity to members of other genera of the $\alpha-3$ subclass, including those of $R$ bodobacter, Rhodovulum and Roseobacter. These data indicate that the genus Paracoccus is a genetically coherent single genus and that strain THI $011^{T}$, as well as $T$. versutus, should be reclassified as members of this genus.

On the basis of the $K_{\text {nuc }}$ values calculated, a neighbour- 
Table 2. Levels of sequence similarity and evolutionary distances for $16 \mathrm{~S}$ rDNAs of strain THI $011^{\top}$, Thiobacillus versutus, and related species belonging to the $\alpha-3$ subclass of the Proteobacteria

The values on the upper right are levels of sequence similarity, and the values on the lower left are $K_{\text {nuc }}$ values.

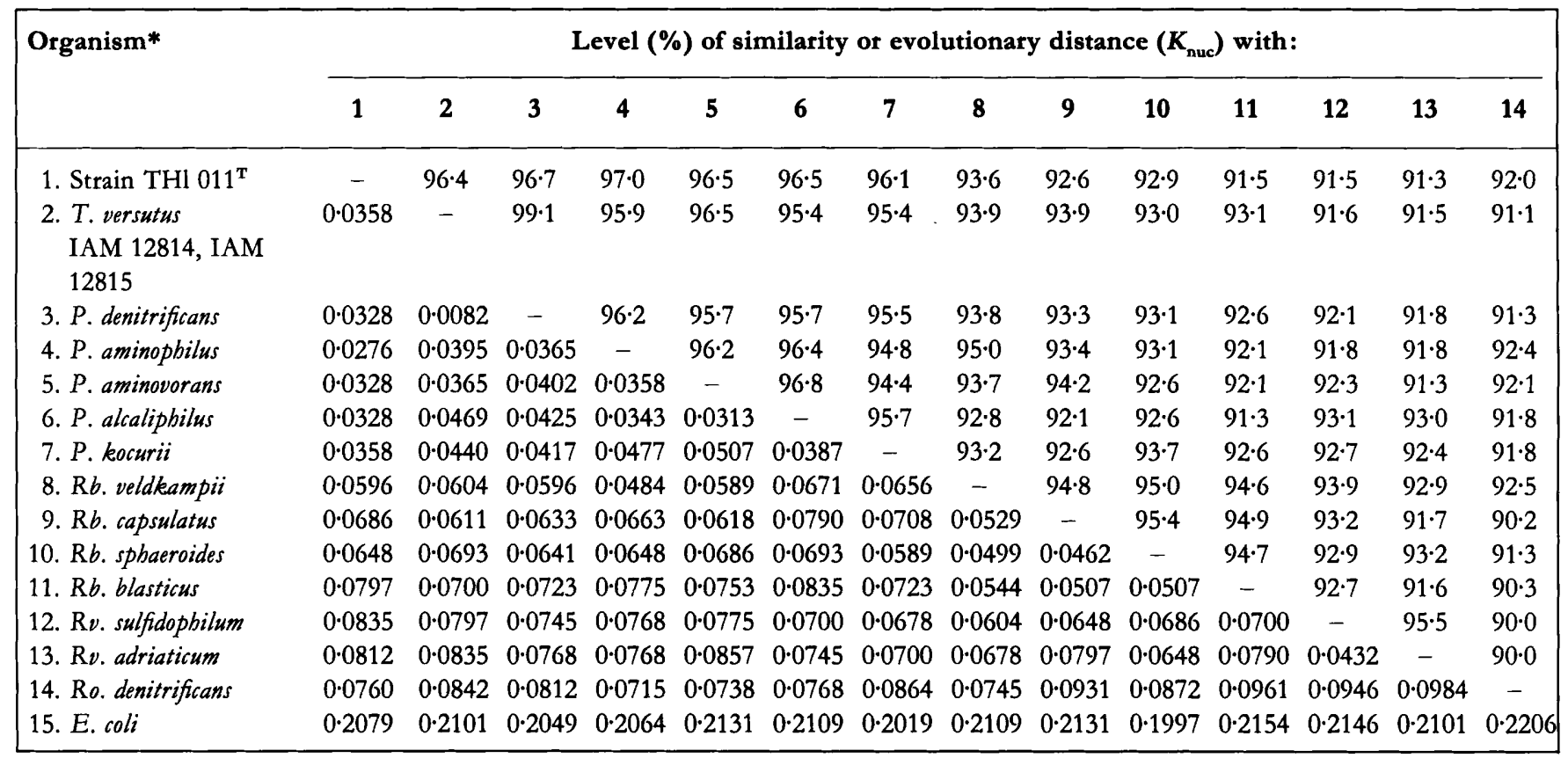

* Rb., Rhodobacter; Rv., Rhodovulum; Ro., Roseobacter.

joining phylogenetic tree was constructed (Fig. 1). As expected from the relatively high levels of interspecies sequence similarity within the genus Paracoccus, members of this genus formed a line of descent separate from the lineage including the genera of the phototrophic bacteria. Strain THI $011^{\mathrm{T}}$ and T. versutus belonged to the cluster of Paracoccus, with $P$. aminophilus and $P$. denitrificans, respectively, as the closest relative. A bootstrap analysis showed that the Paracoccus cluster, including strain THI $011^{\mathbf{T}}$ and $T$. versutus, is relatively stable as a monophyletic group ( $94.5 \%$ support).

\section{Morphology, physiology and biochemistry}

The cells of strain THI $011^{\mathrm{T}}$ were Gram-negative, nonsporeforming, non-acid-alcohol-fast, non-motile rods measuring $0.5-0.7 \mu \mathrm{m}$ in width and $0.8-1.3 \mu \mathrm{m}$ in length, and occurred singly or in pairs (Fig. 2). Electron micrographs of thin sections revealed that polyhedral inclusion bodies were absent from the cells (KatayamaFujimura et al., 1984c), unlike those of Tbiobacillus species of groups II and III. Colonies grown on BY medium were circular, entire, smooth, opaque and reddish yellow, becoming 3-4 $\mathrm{mm}$ in diameter after $2 \mathrm{~d}$ incubation. On thiocyanate medium, colonies were circular, thin, smooth, entire, opaque, yellowish white or creamy white, and $0.4-0.7 \mathrm{~mm}$ in diameter after $8 \mathrm{~d}$ incubation.

Strain THI $011^{\mathrm{T}}$ grew as an aerobic facultative chemolithotroph with a strictly respiratory type of metabolism using oxygen as the terminal electron acceptor. Anaerobic growth was possible when nitrate was present as a terminal electron acceptor in $\mathrm{SM} /$ glucose medium. Nitrate-respiring growth was accompanied by evolution of $\mathrm{N}_{2}$ gas after $10 \mathrm{~d}$ incubation. The organism was neutrophilic and mesophilic: optimal growth occurred at $\mathrm{pH} 7.5-8.5$ (range 6.5-9.5) in BY medium and at pH 7.0-8.0 (range 6.0-8.5) in TC medium; optimum temperature for growth was between 30 and $35^{\circ} \mathrm{C}$ (range $15-40^{\circ} \mathrm{C}$ ). Thiamin was required as a growth factor. The organism was catalase and oxidase positive. A wide variety of organic compounds served as carbon sources: L-alanine, L-serine, L-leucine, L-isoleucine, L-glutamate, L-proline, L-histidine, L-phenylalanine, L-arabinose, D-ribose, D-glucose, D-galactose, fructose, mannitol, $n$ butanol, acetate, propionate, $n$-butyrate, lactate, pyruvate, succinate, glutarate, $m$-hydroxybenzoate and $p$-hydroxybenzoate. Carbon sources supporting weak growth were: ethanol, n-propanol, formate, 2-oxoglutarate and gluconate. The following were not utilized: L-aspartate, L-tryptophan, L-cysteine, maltose, lactose, sucrose, cellobiose, glycerol, methanol, cyclohexanol, citrate, L-malate, oxalate, adipate, pimelate, benzoate, $o$-hydroxybenzoate, $p$-aminobenzoate and DL-mandelate. Ammonium salts and glutamate, but not nitrate, urea or aspartate, were used as nitrogen sources. Gelatin was not hydrolysed.

\section{Utilization of sulphur compounds}

Strain THI $011^{\text {T }}$ was a facultative chemolithotroph when grown with reduced sulphur compounds such as thiocyanate, thiosulphate or elemental sulphur as energy 


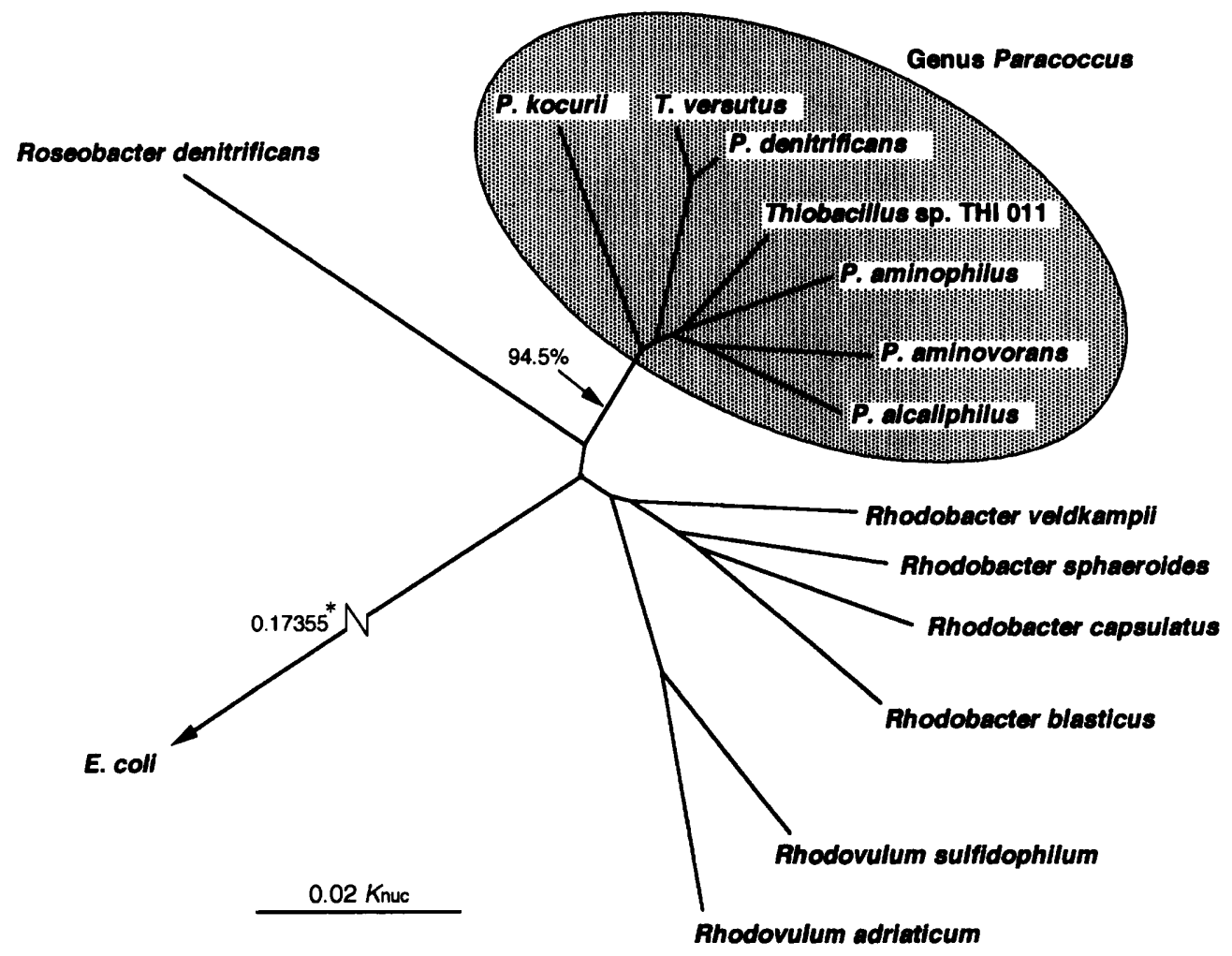

Fig. 1. Distance matrix tree showing phylogenetic affiliations of strain THI $011^{\top}, T$. versutus, Paracoccus species, and related members of the $\alpha-3$ subclass of the Proteobacteria. The bacteria examined for 16S rDNA sequences in this study are indicated by boldface type. A bootstrap confidence value (expressed as a percentage of 1000 bootstrapped trials) is given at the node placing the tested 'thiobacilli' and Paracoccus species as a monophyletic group. *Evolutionary distance $\left(K_{\text {nuc }}\right)$ between $E$. coli and tested organisms in the $\alpha-3$ subgroup.

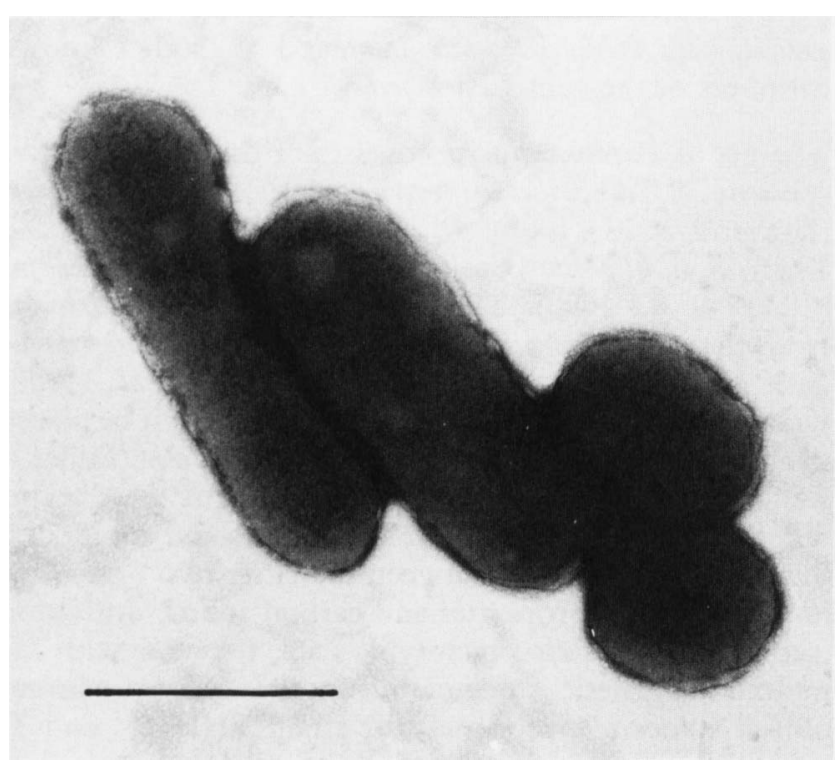

Fig. 2. Electron micrograph of cells of strain THI $011^{\top}$. Cells were negatively stained with phosphotungstic acid. Bar, $1 \mu \mathrm{m}$.

source. The specific growth rate for growth with thiocyanate was $0.059 \mathrm{~h}^{-1}$. During growth in a medium containing $3.5 \mathrm{~g}$ potassium thiocyanate $1^{-1}$, the thiocyanate was degraded with the concomitant production of sulphate, but the $\mathrm{pH}$ of the medium changed little, presumably due to the formation of ammonium and potassium ions. Strain THI $011^{\mathrm{T}}$ also oxidized thiosulphate to sulphate or tetrathionate, depending upon the physiological condition of the cells: heterotrophically grown cells (grown in BY medium) converted thiosulphate to tetrathionate, whereas autotrophically grown cells (grown in TC/thiocyanate medium) oxidized thiosulphate to sulphate. Elemental sulphur was oxidized slowly with a decrease in $\mathrm{pH}$ of the medium from 7.5 to 5.5 during 1-2 weeks incubation. Tetrathionate did not support growth.

\section{Chemotaxonomic characteristics}

Strain THI $011^{\mathbf{T}}$ contained ubiquinones as the sole respiratory quinones, with Q-10 representing $99 \%$ of the total ubiquinone content. It contained $\left[\mathrm{C}_{18: 1}+\mathrm{C}_{19 \mathrm{cyc}}\right]$ as major non-hydroxyl fatty acids, representing about $80 \%$ of the total non-hydroxyl acids. Strain THI $011^{\mathrm{T}}$ also contained 3-hydroxyl fatty acids, with $\mathrm{C}_{10: 0}$ predominating.

\section{Genomic DNA relatedness}

Experiments on genomic DNA relatedness confirmed the taxonomic positions of strain THI $011^{\mathrm{T}}$ and T. versutus, as possible new species of the genus Paracoccus (Table 3). 
Table 3. DNA base composition of and DNA-DNA relatedness among the test organisms

\begin{tabular}{|c|c|c|c|c|c|c|c|c|}
\hline \multirow[t]{2}{*}{ Organism } & \multirow{2}{*}{$\begin{array}{c}G+C \\
\text { content of } \\
\text { DNA } \\
(\mathrm{mol} \%)\end{array}$} & \multicolumn{7}{|c|}{ Level (\%) of hybridization with labelled DNA from: } \\
\hline & & $\underset{\text { THI 011 }^{\mathrm{T}}}{\text { Strain }}$ & $\begin{array}{c}\text { IAM } \\
12814^{T}\end{array}$ & $\begin{array}{c}\text { IAM } \\
12479^{T}\end{array}$ & JCM $7686^{\top}$ & JCM $7685^{T}$ & JCM $7364^{\mathrm{T}}$ & JCM $7684^{\mathrm{T}}$ \\
\hline Strain THI $011^{\mathbf{T}}$ & $66 \cdot 5^{*}$ & 100 & 31 & 23 & 33 & 27 & 31 & 14 \\
\hline Thiobacillus versutus IAM $12814^{\mathrm{T}}$ & $66 \cdot 8$ & 24 & 100 & 49 & 29 & 29 & 31 & 21 \\
\hline Thiobacillus versutus IAM 12815 & $66 \cdot 7$ & 25 & 98 & NT & NT & NT & NT & NT \\
\hline Paracoccus denitrificans IAM $12479^{\mathrm{T}}$ & $66 \cdot 5$ & 29 & 56 & 100 & 26 & 26 & 39 & 16 \\
\hline Paracoccus denitrificans IFO 13301 & $66 \cdot 5$ & 26 & 51 & 89 & NT & NT & NT & NT \\
\hline Paracoccus aminophilus JCM $7686^{\mathrm{T}}$ & $63 \cdot 8$ & 38 & 21 & 32 & 100 & 22 & 34 & 17 \\
\hline Paracoccus aminovorans JCM $7685^{\mathrm{T}}$ & $66 \cdot 8$ & 35 & 26 & 22 & 36 & 100 & 37 & 14 \\
\hline Paracoccus alcaliphilus JCM $7364^{\mathrm{T}}$ & $64 \cdot 6$ & 28 & 22 & 24 & 34 & 34 & 100 & 16 \\
\hline Paracoccus kocurii JCM $7684^{\mathrm{T}}$ & $70 \cdot 2$ & 21 & 18 & 19 & 17 & 15 & 18 & 100 \\
\hline Rbodobacter capsulatus DSM $1710^{\mathbf{T}}$ & $66 \cdot 0$ & 9 & 11 & 12 & 11 & 8 & 9 & 7 \\
\hline Rbodobacter sphaeroides DSM $158^{\mathrm{T}}$ & $69 \cdot 2$ & 12 & 16 & 14 & 14 & 10 & 10 & 8 \\
\hline
\end{tabular}

* Cited from Katayama-Fujimura et al. (1984b).

Hybridization levels of strain THI $011^{\mathrm{T}}$ with T. versutus and Paracoccus species were between 14 and $38 \%$. T. versutus had a relatively high level of hybridization to $P$. denitrificans, but this value is smaller than the lower limit for a single species defined on the basis of DNA-DNA hybridization (approximately $70 \%$ or greater; Wayne $e t$ al., 1987). The G+C content of the DNA from strain THI $011^{\mathrm{T}}$ was $66.5 \mathrm{~mol} \%$ as determined by HPLC of the nuclease P1 hydrolysate of the DNA (Katayama-Fujimura et al., 1984b). The $\mathrm{G}+\mathrm{C}$ content calculated from $T_{\mathrm{m}}$ was $67 \cdot 6 \mathrm{~mol} \%$ (Katayama-Fujimura et al., 1983a).

\section{DISCUSSION}

Utilization of sulphur compounds, including thiocyanate, as energy sources for growth has been found in a variety of chemotrophic bacteria, many of which have little or no taxonomic relationship to each other (Robertson \& Kuenen, 1992). We have presented here the phenotypic, chemotaxonomic and genetic characteristics of a thiocyanate-utilizing facultative chemolithotroph, strain THI $011^{\mathrm{T}}$. To our knowledge, the present study is the first to describe a species of facultatively chemolithotrophic bacterium capable of using thiocyanate as an energy source.

Although strain THI $011^{\mathbf{T}}$ was previously called Thiobacillus sp. because of its ability to grow chemolithotrophically with sulphur compounds, the phylogenetic analysis based on PCR-amplified 16S rDNA sequences (Table 2) demonstrates that this organism belongs to the lineage encompassing members of the genus Paracoccus, with $P$. aminophilus as the nearest neighbour. This strongly implies that the new isolate should be reclassified as a member of the genus Paracoccus. Genomic DNA hybridization levels between strain THI $011^{\mathrm{T}}$ and known Paracoccus species are sufficiently low to warrant classification of the isolate as a new genospecies of Paracoccus. Our phylogenetic data also provide evidence that $T$. versutus is a member of the genus Paracoccus with $P$. denitrificans as the closest relative, supporting previous findings concerning the phylogenetic affiliations of these organisms (Lane et al., 1992; Ludwig et al., 1993). The high level of sequence similarity $(99 \cdot 1 \%)$ between $T$. versutus and $P$. denitrificans indicates their close relationship. Nevertheless, the results of DNA-DNA pairing studies allow separation of $T$. versutus as a distinct genospecies from $P$. denitrificans and any other known members of the genus Paracoccus.

The genus Paracoccus now consists of the following five species: $P$. denitrificans (type species), $P$. aminophilus (Urakami et al., 1990), P. aminovorans (Urakami et al., 1990), P. alcaliphilus (Urakami et al., 1989) and P. kocurii (Ohara et al., 1990). The removal of $P$. balodenitrificans from the genus Paracoccus was recently proposed on the basis of chemotaxonomic traits (Ohara et al., 1990; Urakami et al., 1990) and it was suggested that it be placed in a genus of the $\gamma$ subclass of the Proteobacteria (Miller $e t$ al., 1994). There are a number of major phenotypic differences between the Paracoccus species and strain THI $011^{\mathrm{T}}$ or T. versutus and between the latter two organisms in physiological properties and carbon source utilization (see Table 4). These phenotypic data, together with the molecular genetic information noted above, warrant official taxonomic proposals for strain THI $011^{\mathbf{T}}$ and $T$. versutus as two new species of the genus Paracoccus.

On the basis of these results, we make three taxonomic proposals, as follows: the designation of strain THI 011 ${ }^{\mathrm{T}}$ as a new Paracoccus species with the name Paracoccus thiocyanatus sp. nov.; the transfer of $T$. versutus to the genus Paracoccus as Paracoccus versutus comb. nov. (type strain, IAM 12814); and the resultant emendation of the genus Paracoccus. The differential characteristics of P. thio- 
Table 4. Useful characteristics to differentiate Paracoccus species

\begin{tabular}{|c|c|c|c|c|c|c|c|}
\hline Characteristic & $\begin{array}{l}\text { P. thio- } \\
\text { cyanatus }\end{array}$ & P. versutus & $\begin{array}{c}\text { P. alcali- } \\
\text { philus* }\end{array}$ & $\begin{array}{c}\text { P. amino- } \\
\text { philust }\end{array}$ & $\begin{array}{c}\text { P. amino- } \\
\text { voranst }\end{array}$ & $\begin{array}{l}\text { P. denitri- } \\
\text { ficans }\end{array}$ & P. kocuriił \\
\hline Motility & - & $\pm \delta$ & - & - & - & - & - \\
\hline Nitrate respiration & + & + & - & - & - & + & + \\
\hline \multicolumn{8}{|l|}{ Utilization of: } \\
\hline Glycerol & - & + & + & + & + & + or - & $\mathbf{w}$ \\
\hline Sucrose & - & + & - & - & - & + & - \\
\hline D-Fructose & + & + & + & - & + & + & - \\
\hline Mannitol & + & + & + & - & + & + & - \\
\hline Benzoate & - & + & & & & - & - \\
\hline Thiosulphate & $\mathrm{w}$ & + & & & & + & - \\
\hline Thiocyanate & + & - & & & & & \\
\hline Vitamin requirement & Thiamin & - & Biotin & Thiamin & Thiamin & - & Thiamin \\
\hline
\end{tabular}

* Data from Urakami et al. (1989). †Data from Urakami et al. (1990). † Data from Ohara et al. (1990).

\$ There are positive and negative reports for motility (Harrison, 1983; Katayama-Fujimura et al., 1983b).

cyanatus, $P$. versutus and other members of the genus Paracoccus are shown in Table 4.

Chemolithotrophy, with molecular hydrogen and thiosulphate as the energy sources, is found in P. denitrificans, the type species of the genus Paracoccus. Unfortunately, little information about chemolithotrophic growth of other species of the genus Paracoccus is available; thus we cannot compare the tested 'thiobacilli' with them in this respect. There is a need to study these Paracoccus species for the ability to grow chemolithotrophically with reduced sulphur compounds, including thiocyanate. In this connection, it is interesting to note that members of the phototrophic genera Rbodobacter and Rbodovulum, the phylogenetic neighbours of Paracoccus, can use sulphide or thiosulphate as an electron donor for anaerobic phototrophic growth (Imhoff, 1989; Hiraishi \& Ueda, 1994). Species in the genus Paracoccus differ from the other members of the $\alpha-3$ subgroup of Proteobacteria in their lack of phototrophic growth ability.

\section{Emended description of the genus Paracoccus}

Paracoccus (pa.ra.coc'cus, Gr. prep. para, like, alongside of; Gr. n. coccus, a grain, berry; ML masc. n. Paracoccus, like a coccus).

Cells are spherical or rod-shaped, $0 \cdot 5-1 \cdot 3 \mu \mathrm{m}$ wide and $0.9-2.0 \mu \mathrm{m}$ long, occurring singly, in pairs, in chains or in clusters. No resting stage is known. Gram-negative. Nonmotile (one species is motile, having a tuft of polar flagella). Metabolism is respiratory with oxygen as the terminal electron acceptor. Some species are also able to use nitrate as the acceptor. Aerobic chemoorganotrophs or facultative chemolithotrophs. Facultative chemolithotrophic species utilize reduced sulphur compounds or molecular hydrogen as energy source. Mesophilic, neutrophilic and non-halophilic. Catalase and oxidase positive.
A wide variety of organic compounds are used as carbon and energy sources. Major quinone is Q-10. Major nonhydroxyl fatty acids are $\left[\mathrm{C}_{18: 1}+\mathrm{C}_{19 \mathrm{cyc}}\right]$, which constitute $60-80 \%$ of total non-hydroxyl acids. 3-Hydroxyl fatty acids are present, with 3-OH $\mathrm{C}_{10: 0}$ predominating. Some species also contain 3-OH C $14: 0$. The $\mathrm{G}+\mathrm{C}$ content of the DNA is $64-70 \mathrm{~mol} \%$. Phylogenetic position is the $\alpha-3$ subclass of the Proteobacteria.

Type species: Paracoccus denitrificans ([Beijerinck 1910] Davis 1969, 384) Ludwig et al. 1993.

\section{Description of Paracoccus thiocyanatus sp. nov.}

Paracoccus thiocyanatus (thi.o.cyan'atus, L. m. adj. thiocyanatus thiocyanate; referring to the ability to use thiocyanate).

Cells are rod-shaped, $0.5-0.7 \mu \mathrm{m}$ wide and $0.8-1.3 \mu \mathrm{m}$ long, occurring singly or in pairs. Non-sporeforming. Non-motile. Gram-negative. Not acid-alcohol-fast. Polyhedral inclusion bodies (carboxysomes) are absent in cells. Grows aerobically with oxygen as the terminal electron acceptor. Anaerobic growth is also possible with nitrate as the acceptor in heterotrophic medium, denitrification positive. Neutrophilic and mesophilic. Growth factor requirement is satisfied by thiamin. Facultatively chemolithotrophic and autotrophic. Thiocyanate serves as an energy source. Elemental sulphur is oxidized slowly. Thiosulphate is oxidized to tetrathionate by chemoorganotrophically grown cells or to sulphate by thiocyanate-grown cells. Tetrathionate does not support growth. Various organic compounds, including amino acids, carbohydrates, carboxylic acids, alcohols and aromatic compounds, are assimilated. Gelatin is not liquefied. The G+C content of the DNA is $66.5 \mathrm{~mol} \%$ (HPLC). All other characteristics are as described in Results. Source: activated sludge. Type strain: THI 011 (= IAM 12816). 


\section{Description of Paracoccus versutus [Thiobacillus versutus Harrison 1983, 216 (Thiobacillus rapidicrescens Katayama-Fujimura, Kawashima, Tsuzaki and Kuraishi, 1983, 536)] comb. nov.}

Paracoccus versutus (ver.su'tus. L. adj. versutus versatile).

Cells are rod-shaped, $0.4-0.5 \mu \mathrm{m}$ wide and 1.1-1.7 $\mu \mathrm{m}$ long, occurring singly or in pairs. Non-sporeforming. Motile with a tuft of polar flagella. Gram-negative. Not acid-alcohol-fast. Colonies are circular, wrinkled with raised centre, lobate, spreading, brownish yellow, opaque, becoming 3-4 $\mathrm{mm}$ in diameter after $2 \mathrm{~d}$ incubation on ordinary complex media. On thiosulphate medium, colonies are circular, convex, smooth, entire, creamy white and opaque, developing a brown centre with age, and about $2 \mathrm{~mm}$ in diameter after 1 week. Polyhedral inclusion body is absent in cells. Grows aerobically with oxygen as the terminal electron acceptor. Anaerobic growth is also possible with nitrate as the acceptor; denitrification positive under heterotrophic growth conditions. Optimal growth occurs at $30-37^{\circ} \mathrm{C}$ (range, $17-40{ }^{\circ} \mathrm{C}$ ) and at pH 7.5-8.0 (range, $\mathrm{pH} 6.5-9 \cdot 5$ ) in ordinary complex media and at $\mathrm{pH} 8.0-9.0$ in thiosulphate medium (range, pH 6.5-9.5). Growth factors are not required. Facultatively chemolithotrophic and autotrophic; thiosulphate is utilized as an energy source. Elemental sulphur is oxidized slowly. Tetrathionate or thiocyanate does not support growth. Usable carbon sources are: L-alanine, Lserine, L-leucine, L-isoleucine, L-aspartate, L-glutamate, Lproline, L-histidine, L-phenylalanine, L-arabinose, Dribose, D-glucose, D-galactose, fructose, maltose, sucrose, gluconate, glycerol, mannitol, formate, acetate, propionate, $n$-butyrate, lactate, pyruvate, L-malate, succinate, 2 oxoglutarate, glutarate, adipate, ethanol, $n$-propanol, $n$ butanol, benzoate, $m$-hydroxybenzoate and $p$-hydroxybenzoate. Methanol supports weak growth. Not utilized are: L-tryptophan, L-cysteine, lactose, cellobiose, oxalate, pimelate, cyclohexanol, $o$-hydroxybenzoate, $p$-aminobenzoate and DL-mandelate. There are positive and negative reports for growth on citrate (Wood \& Kelly, 1983; Katayama-Fujimura et al., 1983b). Nitrate and ammonium salts, glutamate and aspartate, but not urea, are utilized as nitrogen sources. Gelatin is not hydrolysed. The $G+C$ content of the DNA is $67-68 \mathrm{~mol} \%$. All other characteristics are the same as those for the genus. Source: soil. Type strain: IAM 12814 (= ATCC 25364).

\section{ACKNOWLEDGEMENTS}

We thank Professor K. Komagata, Tokyo University of Agriculture, for discussions and encouragement, and Ms Y. Ueda and Mr K. Muramatsu, Konishi Co., for performing PCR amplification of the $16 \mathrm{~S}$ rRNA genes.

\section{REFERENCES}

Beijerinck, M. W. (1910). Bildung und Verbrauch von Stickoxydul durch Bakterien. Zentralbl Bakteriol Parasitenkd Infektionskr Abt 2 25, 30-63.

Betts, P. M., Rinder, D. F. \& Fleeker, J. R. (1979). Thiocyanate utilization by an Artbrobacter. Can J Microbiol 25, 1277-1282.

Brosius, J., Palmer, M. L., Kennedy, J. P. \& Noller, H. F. (1978).
Complete nucleotide sequence of a 16S ribosomal RNA gene from Escherichia coli. Proc Natl Acad Sci US A 75, 4801-4805.

Davis, D. H., Doudoroff, M. \& Stanier, R. Y. (1969). Proposal to reject the genus Hydrogenomonas: taxonomic implications. Int J Syst Bacteriol 19, 375-390.

Drobner, E., Huber, H., Rachel, R. \& Stetter, K. O. (1992). Thiobacillus plumbophilus spec. nov., a novel galena and hydrogen oxidizer. Arch Microbiol 157, 213-217.

Ezaki, T., Dejsirilert, S., Yamamoto, H., Takeuchi, N., Liu, S. \& Yabuuchi, E. (1988). Simple and rapid genetic identification of Legionella species with photobiotin-labeled DNA. J Gen Appl Microbiol 34, 191-199.

Felsenstein, J. (1985). Confidence limits on phylogenies: an approach using the bootstrap. Evolution 39, 783-791.

Happold, F. C., Johnstone, K. I., Rogers, H. J. \& Youatt, J. B. (1954). The isolation and characteristics of an organism oxidizing thiocyanate. J Gen Microbiol 10, 261-266.

Happold, F. C., Jones, G. L. \& Pratt, D. B. (1958). Utilization of thiocyanate by Thiobacillus thioparus and T. thiocyanoxidans. Nature 182, 266-267.

Harrison, A. P., Jr (1983). Genomic and physiological comparisons between heterotrophic thiobacilli and Acidipbilium cryptum, Thiobacillus versutus sp. nov., and Thiobacillus acidophilus nom. rev. Int J Syst Bacteriol 33, 211-217.

Higgins, D. G., Bleasby, A. J. \& Fuchs, R. (1992). Clustal v: improved software for multiple sequence alignment. Comput Appl Biosci 8, 189-191.

Hiraishi, A. (1992). Direct automated sequencing of $16 \mathrm{~S} \mathrm{rDNA}$ amplified by polymerase chain reaction from bacterial cultures without DNA purification. Lett Appl Microbiol 15, 210-213.

Hiraishi, A. \& Ueda, Y. (1994). Intrageneric structure of the genus Rhodobacter: transfer of Rhodobacter sulfidopbilus and related marine species to the genus Rbodovulum gen. nov. Int J Syst Bacteriol 44, 15-23.

Hiraishi, A., Hoshino, Y. \& Satoh, T. (1991). Rhodoferax fermentans gen. nov., sp. nov., a phototrophic purple nonsulfur bacterium previously referred to as the 'Rhodocyclus gelatinosus-like' group. Arch Microbiol 155, 330-336.

Hiraishi, A., Shin, Y. K., Ueda, Y. \& Sugiyama, J. (1994). Automated sequencing of PCR-amplified 16S rDNA on 'Hydrolink' gels. $J$ Microbiol Methods 19, 145-154.

Huber, H. \& Stetter, K. O. (1990). Thiobacillus cuprinus sp. nov., a novel facultatively organotrophic metal-mobilizing bacterium. Appl Environ Microbiol 56, 315-322.

Hutchinson, M., Johnstone, K. I. \& White, D. (1969). Taxonomy of the genus Thiobacillus: the outcome of numerical taxonomy applied to the group as a whole. J Gen Microbiol 57, 397-410.

Imhoff, J. F. (1989). Genus Rbodobacter Imhoff, Trüper and Pfennig $1984,342^{\mathrm{VP}}$. In Bergey's Manual of Systematic Bacteriology, vol. 3, pp. 1668-1672. Edited by J. T. Staley, M. P. Bryant, N. Pfenning \& J. G. Holt. Baltimore: Williams \& Wilkins.

Jackson, J. F., Moriarty, D. J. W. \& Nicholas, D. J. D. (1968). Deoxyribonucleic acid base composition and taxonomy of thiobacilli and some nitrifying bacteria. J Gen Microbiol 53, 53-60.

Katayama, Y. \& Kuraishi, H. (1978). Characteristics of Thiobacillus thioparus and its thiocyanate assimilation. Can J Microbiol 24, 804-810.

Katayama, Y., Narahara, Y., Inoue, Y., Amano, F., Kanagawa, T. \& Kuraishi, H. (1992). A thiocyanate hydrolase of Thiobacillus thioparus: a novel enzyme catalyzing the formation of carbonyl sulfide from thiocyanate. $J$ Biol Chem 267, 9170-9175. 
Katayama-Fujimura, Y. \& Kuraishi, H. (1980). Characterization of Thiobacillus novellus and its thiosulfate oxidation. J Gen Appl Microbiol 26, 357-367.

Katayama-Fujimura, Y., Tsuzaki, N. \& Kuraishi, H. (1982). Ubiquinone, fatty acid and DNA base composition determination as a guide to the taxonomy of the genus Thiobacillus. J Gen Microbiol 128, 1599-1611.

Katayama-Fujimura, Y., Enokizono, Y., Kaneko, T. \& Kuraishi, H. (1983a). Deoxyribonucleic acid homologies among species of the genus Tbiobacillus. J Gen Appl Microbiol 29, 287-295.

Katayama-Fujimura, Y., Kawashima, I., Tsuzaki, N. \& Kuraishi, H. (1983b). Reidentification of Thiobacillus perometabolis ATCC 27793 and Thiobacillus sp. strain A2 with reference to a new species, Thiobacillus rapidicrescens sp. nov. Int J Syst Bacteriol 33, 532-538.

Katayama-Fujimura, Y., Kawashima, I., Tsuzaki, N. \& Kuraishi, H. (1984a). Physiological characteristics of the facultatively chemolithotrophic Thiobacillus species, Tbiobacillus delicatus nom. rev., emend., Thiobacillus perometabolis, and Thiobacillus intermedius. Int J Syst Bacteriol 34, 139-144.

Katayama-Fujimura, Y., Komatsu, Y., Kuraishi, H. \& Kaneko, T. (1984b). Estimation of DNA base composition by high performance liquid chromatography of its nuclease P1 hydrolysate. Agric Biol Chem 48, 3169-3172.

Katayama-Fujimura, Y., Tsuzaki, N., Hirata, A. \& Kuraishi, H. (1984c). Polyhedral inclusion bodies (carboxysomes) in Tbiobacillus species with reference to the taxonomy of the genus Thiobacillus. $J$ Gen Appl Microbiol 30, 211-222.

Kelly, D. P. \& Harrison, A. P. (1989). Genus Thiobacillus Beijerinck $1904,597^{\mathrm{AL}}$. In Bergey's Manual of Systematic Bacteriology, vol. 3, pp. 1842-1858. Edited by J. T. Staley, M. P. Bryant, N. Pfenning \& J. G. Holt. Baltimore: Williams \& Wilkins.

Kimura, M. (1980). A simple method for estimating evolutionary rates of base substitution through comparative studies of nucleotide sequences. J Mol Evol 16, 111-120.

Lane, D. J., Harrison, A. P., Jr, Stahl, D., Pace, B., Giovannoni, S. J., Olsen, G. J. \& Pace, N. R. (1992). Evolutionary relationships among sulfur- and iron-oxidizing eubacteria. $J$ Bacteriol 174, 269-278.

Ludwig, W., Mittenhuber, G. \& Friedrich C. G. (1993). Transfer of Thiosphaera pantotropha to Paracoccus denitrificans. Int J Syst Bacteriol 43, 363-367.

Marmur, J. (1961). A procedure for the isolation of deoxyribonucleic acid from micro-organisms. $J$ Mol Biol 3, 208-218.

Miller, J. M., Dobson, S. J., Franzmann, P. D. \& McMeekin, T. A. (1994). Reevaluating the classification of Paracoccus balodenitrificans with sequence comparisons of $16 \mathrm{~S}$ ribosomal DNA. Int $J$ Syst Bacteriol 44, 360-361.
Ohara, M., Katayama, Y., Tsuzaki, M., Nakamoto, S. \& Kuraishi, H. (1990). Paracoccus kocurii sp. nov., a tetramethylammoniumassimilating bacterium. Int J Syst Bacteriol 40, 292-296.

Putilina, N. T. (1961). Bacteria of sewage waters of coke factories oxidizing thiocyanate and cyanide compounds. Mikrobiologiya $\mathbf{3 0}$, 294-308 (in Russian).

Robertson, L. A. \& Kuenen, J. G. (1992). The colorless sulfur bacteria. In The Prokaryotes, 2nd edn, vol. 1. pp. 385-413. Edited by A. Balows, H. G. Trüper, M. Dworkin, W. Harder \& K.-H. Schleifer. New York: Springer.

Saitou, N. \& Nei, M. (1987). The neighbor-joining method: a new method for reconstructing phylogenetic trees. Mol Biol Evol 4, 406-425.

Stackebrandt, E., Murray, R. G. E. \& Truper, H. G. (1988). Proteobacteria classis nov., a name for the phylogenetic taxon that includes the 'purple bacteria and their relatives'. Int J Syst Bacteriol 38, 321-325.

Stafford, D. A. \& Callely, A. G. (1969). The utilization of thiocyanate by a heterotrophic bacterium. J Gen Microbiol 55, 285-289.

Urakami, T., Tamaoka, J., Suzuki, K. \& Komagata, K. (1989). Paracoccus alcaliphilus sp. nov., an alkaliphilic and facultatively methylotrophic bacterium. Int J Syst Bacteriol 39, 116-121.

Urakami, T., Araki, H., Oyanagi, H., Suzuki, K. \& Komagata, K. (1990). Paracoccus aminophilus sp. nov. and Paracoccus aminovorans sp. nov., which utilize $N, N^{\prime}$-dimethylformamide. Int I Syst Bacteriol 40, 287-291.

Vishniac, W. V. (1974). Genus Thiobacillus. In Bergey's Manual of Determinative Bacteriology, pp. 456-461. Edited by R. E. Buchanan \& N. E. Gibbons. Baltimore: Williams \& Wilkins.

Wayne, L. G., Brenner, D. J., Colwell, R. R., Grimont, P. A. D., Kandler, O., Krichevsky, M. I., Moore, L. H., Moore, W. E. C., Murray, R. G. E., Stackebrandt, E., Starr, M. P. \& Truper, H. G. (1987). Report of the ad hoc Committee on Reconciliation of Approaches to Bacterial Systematics. Int J Syst Bacteriol 37, 463- 464.

Woese, C. R. (1987). Bacterial evolution. Microbiol Rev 51, 221-271.

Wood, J. L (1975). Biochemistry. In Chemistry and Biochemistry of Thiocyanic Acid and Its Derivatives, pp. 156-212. Edited by A. A. Newman. London: Academic Press.

Wood, A. P. \& Kelly, D.P. (1983). Use of carboxylic acids by Thiobacillus A2. Microbios 38, 15-25.

Youatt, J. B. (1954). Studies on the metabolism of Thiobacillus thiocyanoxidans. J Gen Microbiol 11, 139-149.

Received 20 September 1994; revised 24 January 1995; accepted 2 February 1995. 